\title{
Marnix Beyen et Brecht Deseure, Local Memories in a Nationalizing and Globalizing World
}

\author{
Karla Vanraepenbusch
}

\section{(2) OpenEdition}

1 Journals

\section{Édition électronique}

URL : https://journals.openedition.org/temoigner/4823

DOI : 10.4000/temoigner.4823

ISSN : 2506-6390

Éditeur :

Éditions du Centre d'études et de documentation Mémoire d'Auschwitz, Éditions Kimé

\section{Édition imprimée}

Date de publication : 2 mai 2016

Pagination : 159-160

ISSN : 2031-4183

\section{Référence électronique}

Karla Vanraepenbusch, «Marnix Beyen et Brecht Deseure, Local Memories in a Nationalizing and Globalizing World», Témoigner. Entre histoire et mémoire [Online], 122 | 2016, Online op 30 septembre 2021, geraadpleegd op 03 janvier 2022. URL: http://journals.openedition.org/temoigner/4823 ; DOI: https://doi.org/10.4000/temoigner.4823

Ce document a été généré automatiquement le 3 janvier 2022.

Tous droits réservés 


\title{
Marnix Beyen et Brecht Deseure, Local Memories in a Nationalizing and Globalizing World
}

\author{
Karla Vanraepenbusch
}

\section{RÉFÉRENCE}

Marnix Beyen, Brecht Deseure, Local Memories in a Nationalizing and Globalizing World, Palgrave Macmillan, 2015, $280 \mathrm{p}$.

1 Lokale, nationale en transnationale herinneringen vormen een driehoeksrelatie, zo meent historicus Marnix Beyen in de introductie van het boek Local Memories in a Nationalizing and Globalizing World. Beyens zet zich hierin af tegen het vooropgezette idee om de geschiedenis van de herinnering te interpreteren door de lens van de modernisering. Hij beschouwt de collectieve herinneringen van premoderne samenlevingen niet vanzelfsprekend als lokaal, en die van onze moderne maatschappij als nationaal en transnationaal, maar benadrukt juist dat ze altijd, doorheen de negentiende en twintigste eeuw, het resultaat waren van talrijke en continue onderhandelingen tussen deze drie niveaus. Beyen betreurt bovendien dat historici overdreven veel aandacht besteden aan de rol van elites bij de productie van collectieve herinneringen. Volgens hem delen personen herinneringen en identiteiten, niet enkel omdat de elite hun die oplegt, maar ook omdat ze op dezelfde plaatsen leven. Local Memories in a Nationalizing and Globalizing World is dus een boek dat de lokale constructie van herinneringen bestudeert, en ook, zoals de titel aangeeft, de nationale en transnationale tendensen die daarop invloed uitoefenen.

2 De andere bijdragen aan het boek zijn gevalstudies die telkens de stelling van de driehoeksrelatie tussen lokale, nationale en transnationale herinneringen onderschrijven. Het boek bundelt in feite de akten van een internationale conferentie die in 2009 plaatsvond in Antwerpen. De bijdragen zijn zeer divers, eerst en vooral met 
betrekking tot de geografische ruimte die ze bestrijken, van België (Antwerpen) tot Japan en Brazilië. Ze zijn ook divers wat thema's en benaderingen betreft: discoursanalyse van politieke elites, straatnaamveranderingen, de moeizame verzoening rond de graven van oude vijanden, de representatie van de slavenhandel in tentoonstellingen, enzovoort. De indeling van het boek in twee delen compenseert het schijnbare gebrek aan coherentie. Het eerste deel groepeert de hoofdstukken gewijd aan de politiek van stedelijke herinneringen. Deze bijdragen hebben gemeenschappelijk dat ze het accent leggen op de wijze waarop politieke elites en dominante sociale groepen de biografie van een stad vervaardigden. Het tweede deel brengt de bijdragen bijeen over herinneringsplaatsen en-praktijken van 'subalterne' groepen, of, met andere woorden, over de constructie van lokale herinneringen door de achtergestelden en verliezers van de geschiedenis. Het boek besteedt dus zowel aandacht aan top-down als aan from below benaderingen.

3 Local Memories in a Nationalizing and Globalizing World is een boek dat in het kader past, zonder dat de auteurs zich daarop beroepen, van de debatten die de transnational turn in Memory Studies de laatste tien jaar opleverden. In de voetsporen van Aleida Assmann, Astrid Erll, Michael Rothberg, en Daniel Levy en Natan Sznaider, tonen steeds meer auteurs interesse voor herinneringspraktijken over de nationale grenzen heen. Zij gaan in tegen het heersende paradigma van de herinneringsplaatsen, een concept dat wijdverspreid raakte door de publicatie, onder leiding van Pierre Nora, van het werk Les lieux de mémoire, dat territorialiteit, natie en identiteit met elkaar verbindt. Deze auteurs analyseren daarentegen nationale herinneringen in de context van een geglobaliseerde wereld, waarin herinneringen reizen, elkaar beïnvloeden en zich vermengen, en die zij bestempelen als travelling, transcultural, multidirectional of cosmopolitan. Het hier besproken boek is een belangrijke bijdrage aan deze literatuur over nationale en transnationale herinneringen, omdat het de vraag stelt, tot nu toe schromelijk verwaarloosd, van de plaats et de relevantie van lokale herinneringen in deze configuratie.

4 Het boek Local Memories in a Nationalizing and Globalizing World mist nochtans substantie om echt dienst te kunnen doen als referentieboek in de epistemologie van Memory Studies. De auteurs slagen er wel in om ons te overtuigen van het belang van de lokale factor in de constructie van collectieve herinneringen, wat Marnix Beyen in zijn introductie als doelstelling aangaf. De geselecteerde gevalstudies zijn allemaal, zonder uitzondering, interessant en relevant. En de auteurs slagen erin, terwijl ze de driehoeksrelatie tussen lokale, nationale en transnationale herinneringen bestuderen, om twee benaderingen te verzoenen die nog al te vaak beschouwd worden als tegenovergestelden, namelijk de culturalistische en de transnationale benadering in Memory Studies. Dit boek overstijgt echter niet de status van conferentiebundel, omdat een diepgaande theoretische en methodologische reflectie ontbreekt. Het concept van lokale herinneringen wordt pas gedefinieerd in de tweede helft van het boek (p. 141), en het is onduidelijk of de andere auteurs met die definitie akkoord gaan. De meeste auteurs presenteren hun onderzoeksresultaten zonder de methodologie of de bronnen te preciseren waarop die resultaten steunen. Er ontbreekt tenslotte een conclusie waarin de redacteurs de beperkingen en de toekomstige mogelijkheden van het onderzoek naar lokale herinneringen in vraag hadden kunnen stellen. De lezer die interesse heeft voor het concept van lokale herinneringen en voor de epistemologie daarvan blijft dus een beetje op zijn of haar honger zitten. 


\section{AUTEURS}

KARLA VANRAEPENBUSCH

UCL, CegeSoma 